\title{
EFFECT OF COAGULATING AND CUTTING CURRENT ON A DEMAND PACEMAKER DURING TRANSURETHRAL RESECTION OF THE PROSTATE. A CASE REPORT
}

\author{
Y.K. BATRA AND I.M. BALI
}

IMPLANTATION OF CARDIAC PACEMAKERS has increased the life expectancy of many patients considerably. One of the indications for their insertion is the Stokes-Adams syndrome associated with heart block which usually occurs in the sixth and seventh decades of life. In this age group there is a high incidence of prostatic enlargement requiring surgical intervention and, in many, transurethral resection is the procedure of choice. During resection of the prostate electrical interference with the pacemaker by surgical diathermy can lead to cardiac irregularities and even standstill." The purpose of this paper is to describe the effect of coagulating and cutting electrocautery in a patient with a demand pacemaker during transurethral resection of the prostate.

\section{CASE Report}

A man 60 years of age was admitted with a history of recurrent attacks of giddiness and loss of consciousness. An electrocardiogram showed a third degree atrio-ventricular block. A Medtronic series 5945 demand pacemaker was implanted under local anaesthesia in a pocket superficial to the pectoral fascia with a unipolar lead in the endocardium, which maintained the pulse rate at 70 beats per minute. During the hospital stay he was found to have benign prostatic hypertrophy causing urinary obstruction - an indication for transurethral resection. After premedication with morphine $10 \mathrm{mg}$ and promethazine $25 \mathrm{mg}$ intramuscularly, the prostate was resected transurethrally under epidural analgesia using $25 \mathrm{ml}$ of 1.5 per cent lidocaine. The operation took $\mathbf{4 0}$ minutes and was weil tolerated by the patient. No blood replacement was required.

Apart from various safety precautions taken during the procedure, ${ }^{2}$ continuous electrocardiographic records were taken. Figure 1 shows

Y.K. Batra, M.D. Senior Resident, and I.M. Bali, M.S. (Surg.), M.S. (Anaes.), Ph.D. F.F.A.R.C.S. Associate Professor, Department of Anaesthesiology, Post Graduate Institute of Medical Education and Research, Chandigarh, India.

Canad. Anaesth. Soc. J., vol. 25, no. 1, January 1978

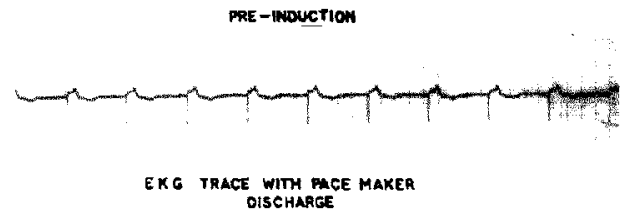

FIGURE 1. Pre-induction electrocardiogram showing pacemaker discharge.

the electrocardiographic tracing before induction of anaesthesia. When the coagulating current was applied for haemostatsis, the electrocardiographic pattern did not change (Figure 2), whereas the application of a prolonged cutting current caused interference with the pacemaker activity leading to a period of asystole (Figure $3 \mathrm{~A})$. Fortunately, with the removal of the interfering signal, the pacemaker function returned to normal. Thereafter the resection was completed with short bursts of cutting current (Figure 3B). No further change in pacemaker activity was encountered.

\section{Discussion}

Pacemakers have been subject to interference from a variety of external sources. ${ }^{3}$ Hazards associated with the use of diathermy in the presence of certain implantable pacemakers are well documented. Lichter, et al..$^{4}$ have twice observed ventricular fibrillation induced by surgical diathermy. Greene, et $a l^{5}$ have recommended that diathermy should not be used at any time in the presence of an external demand unit, nor should it be used within twelve inches of an implanted

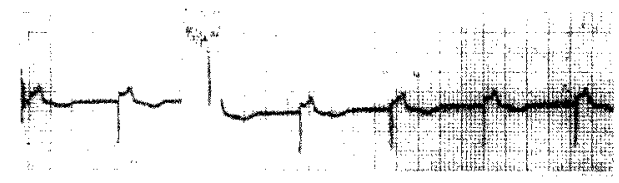

COAGULATION CURRENT

FIGURE 2. Application of coagulating current did not interfere with the pacemaker activity. 


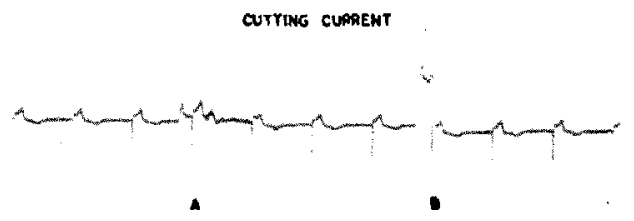

Figure 3A. Use of prolonged cutting current deactivated the pacemaker showing a period of asystole.

Figure 3B. Short bursts of cutting did not influence the pacemaker.

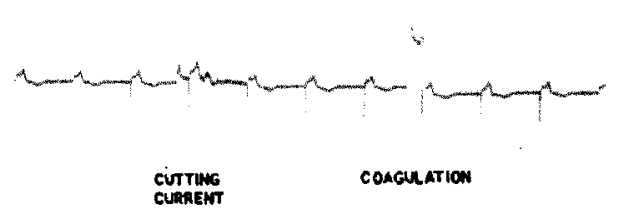

Figure 4. Application of cutting current (short bursts) and coagulating current did not suppress the demand pacemaker.

demand or synchronous P-wave pacemaker. Fein $^{6}$ has described four operations on three patients with implanted fixed rate pacemakers without any interference. He has recommended the proper grounding of all medical electronic equipment and to keep the electrocautery circuit below the pacemaker by placing the electrocautery ground plate as low as possible. Wajszczuk and coworkers ${ }^{7}$ and Lerner ${ }^{8}$ have reported suppression of demand pacemakers by electrocautery.

The surgical diatherny unit employed is quoted as having a frequency in the range 1 to 3.5 $\mathrm{MHz}$ with modulation at $120 \mathrm{~Hz}^{9}$ and interference by this current can cause triggering of a pacemaker. Demand pacemakers have the inherent property that they may detect electrical activity from sources other than heart and this may alter their working. The present case clearly demonstrates that a prolonged cutting current can cause malfunction of the pacemaker while short bursts of cutting current are well tolerated. The coagulating current did not modify the function of the pacemaker.

\section{SUMMARY}

Electromagnetic interference from diathermy apparatus can be a real hazard in a patient with a demand pacemaker. A case is reported in which the cutting current of transurethral electrocaut- ery deactivated an implanted pacemaker, while coagulating current did not alter pacemaker activity. Therefore frequent short bursts of cutting current were used for successful resection of the prostate. This case emphasizes the need for vigilant care of patients with demand pacemakers requiring transurethral resection.

\section{RÉSUMÉ}

L'usage d'un électrocautère chez un malade porteur d'un pacemaker sentinelle, crêe de l'interférence électro-magnétique et peut s'avérer désastreux pour le malade. Les auteurs rapportent le cas d'un malade porteur d'un pacemaker de ce genre et soumis à une résection transurétrale de la prostate. Lorsque le bistouri électrique était utilisé pour couper, il inhibait le pacemaker, alors que son usage pour coaguler ne causait pas de problème. Le patient a quand même pu être opéré sans incident en limitant l'usage du bistouri à de brefs instants à la fois sous monitoring attentif de l'ECG. Ce cas illustre le besoin d'une vigilance de tous les instants lorsque des malades porteurs d'un pacemaker sentinelle sont soumis à une résection transurétrale de la prostate.

\section{REFERENCES}

I. Sowton, E., Gray, K., \& Preston, T. Electrical interference in non-competitive pacemakers. Brit. Heart J. 32 : 626 (1970).

2. Scotr, D.L. Cardiac pacemakers as an antesthetic problem. Anaesthesia 25: 87 (1970).

3. Burchell, H.B. Electroshock hazards. Circulation $41: 17$ (1970).

4. Lichter, I., Borrie, J., \& Millar, W.M. Radiofrequency hazards with cardiac pacemakers. Brit. Med. J. 2: 1513 (1965).

5. Greene, L.F., Myers, G.H., \& McCallister, B.D. Transurethral resection of prostate in patients with cardiac pacemakers. Brit. J. Urol. 4/: 572 (1969).

6. FEIN, R.L. Transurethral electrocautery procedures in patients with cardiac pacemakers. J.A.M.A. 202: 101 (1967).

7. Wajszczuk, W.J., Mowry, F.M., \& Dugan, N.L. Deactivation of a demand pacemaker by transurethral electrocautery. N. Eng. J. Med. 280: 34 (1969).

8. Lerner, S.M. Suppression of a demand pacemaker by transurethral electrocautery. Anesthesia and Analgesia 52: 703 (1973).

9. HILL, D.W. Electronic techniques in anaesthesia and surgery, 2nd ed., London: Butterworths, pp. 343 (1973). 